\title{
List of case reports and diagnoses published in this issue
}

Case report

Open quiz solution: Case report 854

by P.M. Tecce, R.H. Hruban,

E.K. Fishman 648

Case report 873

by M. Grieten, K.A. Buckwalter,

E. Cardinal, B. Rougraff 652

Case report 874

by R.D. Snow, M.D. Christianson,

E.A. Dowling, B.G. Brogdon 656

Case report 875

by A. Zwass, F. Feldman 660

Case report 876

by T. Pevny, R.J. Rooney 664

Case report 877

by Y. Oda, Y. Iwamoto, M. Ushijima,

S. Masuda, Y. Sugioka, M. Tsuneyoshi

669

Case report 878

by J.R. Maxwell, L. Yao, J.J. Eckardt,

S.A. Doberneck 673

Case report 879

by D.R. Lewis, Jr., C.S. Resnik,

S.C. Aisner, A.M. Levine 677

\author{
Diagnosis
}

Eosinophilic granuloma 650

Lipoma arborescens (villous lipomatous proliferation of the synovial membrane) 654

Left supraorbital osteoblastoma 658

Multifocal osteomyelitis - a manifestation of chronic brucellosis 662

Aneurysmal bone cyst of the patella 666

Giant cell reparative granuloma arising in enchondromatosis 670

Densely calcifying synovial sarcoma of the hip metastatic to the lungs 674

Chondrosarcoma of the spinous process 678 